\title{
Improving the storage of minimally processed mangoes (Mangifera indica L.) by hot water treatments
}

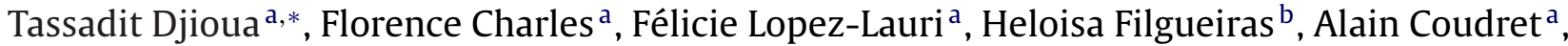 \\ Murillo Freire $\mathrm{Jr}^{\mathrm{c}}{ }^{\mathrm{c}}$, Marie-Noëlle Ducamp-Collin ${ }^{\mathrm{d}}$, Huguette Sallanon ${ }^{\mathrm{a}}$ \\ a Université d'Avignon et des Pays de Vaucluse, Laboratoire Physiologie des Fruits et Légumes, F-84018 Avignon, France \\ ${ }^{\mathrm{b}}$ Embrapa Labex Europe, Avenue Agropolis Cedex 5, 34394 Montpellier, France

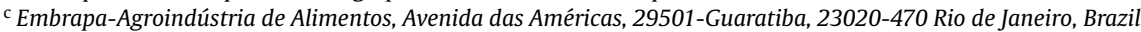 \\ d French Agricultural Research Centre for International Development, TA B 95/16, Avenue Agropolis, 34398 Montpellier Cedex 5, France
}

\section{A R T I C L E I N F O}

\section{Article history:}

Received 23 June 2008

Accepted 13 October 2008

\section{Keywords:}

Heat treatment

Fresh-cut mangoes

Quality

Antioxidants

Respiration rate

\begin{abstract}
A B S T R A C T
Postharvest degradation of minimally processed mangoes limits the marketability of fruit. The effect of heat treatments applied to whole 'Keitt' mango fruit on physical, physiological and biochemical quality of minimally processed mangoes was studied. Whole mangoes were subjected to hot water dipping (HWD) at 46 or $50^{\circ} \mathrm{C}$ for 30 or $75 \mathrm{~min}$, cooled for $15 \mathrm{~min}$, minimally processed and stored at $6^{\circ} \mathrm{C}$ for 9 d. Sensory analysis, firmness, color, acidity, $\mathrm{pH}$, total soluble solids (TSS), ascorbic acid, total carotenoids, malondialdehyde (MDA) and respiration rate (RR) were investigated. A global beneficial effect of HWD $50{ }^{\circ} \mathrm{C} / 30 \mathrm{~min}$ was observed. This treatment was the only one to maintain the acceptability of fresh-cut mangoes for $6 \mathrm{~d}$, the yellow color, expressed by $b^{*}$ value, for $9 \mathrm{~d}$ and the firmness for $3 \mathrm{~d}$ compared to the control. Moreover, HWD $50{ }^{\circ} \mathrm{C} / 30 \mathrm{~min}$ increased the total carotenoids content after $3 \mathrm{~d}$ compared to the control. Although the ascorbic acid content decreased during storage, $\mathrm{HWD} 50{ }^{\circ} \mathrm{C} / 30 \mathrm{~min}$ is the less degrading condition of the heat treatments. Lipid peroxidation, estimated by MDA content, was less important for $\operatorname{HWD~} 50^{\circ} \mathrm{C} / 30 \mathrm{~min}$. Finally, the RR of whole mangoes treated by $\operatorname{HWD~} 50^{\circ} \mathrm{C} / 30 \mathrm{~min}$ was lower than in the other treatments and could be used as an indicator of product shelf-life. This study selected the HWD $50{ }^{\circ} \mathrm{C} / 30 \mathrm{~min}$ as the optimal heat treatment to improve the quality of fresh-cut 'Keitt' mangoes.
\end{abstract}

(c) 2008 Elsevier B.V. All rights reserved.

\section{Introduction}

Mango (Mangifera indica L.) is one of the most important tropical fruit worldwide in terms of production and consumer acceptance (FAO STAT, 2005). Mango fruit is considered as a source of antioxidants including ascorbic acid (mango fruit provides about 50\% of the recommended daily intake of vitamin C) and carotenoids. Carotenoids, which are lipophilic radical scavengers found in many fruits and vegetables are also responsible of the bright yellow color of mango (Vinci et al., 1995; Shieber et al., 2000). In recent years, mangoes have become well established as fresh fruit in the global market but suffer from convenience.

Fresh-cut or minimally processed fruit (peeled, cored and sliced) are a growing segment among food products due to the convenience and fresh-like quality of the products (Pittia et al., 1999;

\footnotetext{
* Corresponding author. Tel.: +33490842217.

E-mail addresses: tassora@gmail.com, tassadit.djioua@etd.univ-avignon.fr (T. Djioua).
}

Charles et al., 2003). Consumers judge the quality of fresh-cut fruit on the basis of appearance and freshness at the time of purchase (Kader, 2002). Rapid deterioration of fruit during handling, transport and storage is a damaging problem. Moreover, fresh-cut processing increases metabolic activity, and decompartmentalization of enzymes and substrates which may cause browning, softening and decay (Varoquaux and Wiley, 1994; Charles et al., 2005). Postharvest losses in nutritional quality can be substantial, for example with decreases in vitamin $C$ and carotenoid contents (Mc Carthy and Mattews, 1994; Sudhakar and Maini, 1994). Freshcut tropical fruit, such as mangoes, are more perishable than those from temperate climates, such as apples and peaches. It is therefore important to control deterioration processes in order to maintain quality.

Much research has focused on the use of postharvest treatments to extend shelf-life, for example with the addition of antioxidants (ascorbic acid), firming agents (calcium derivatives) and modified atmosphere packaging with reduced oxygen levels. Although some of these treatments were found to be effective, consumers are increasingly demanding a reduction in the overall use of 
chemicals on fresh products and alternative methodologies should be investigated. During the past few years, the use of heat treatments applied by hot water, vapour heat or heat air, has increased in order to control insect pests, prevent fungal rots and increase resistance to chilling injury (Lurie, 1998). Heat treatments also inhibited ripening, softening and improved postharvest quality. This was observed in the case of whole fruit, with apples (Klein and Lurie, 1990), strawberries (Garcia et al., 1995; Civello et al., 1997), citrus fruit (Porat et al., 2000) and mangoes (Jacobi and Giles, 1997; Benitez et al., 2006). With regard to fresh-cut products, heat treatments also have been shown to delay ripening and senescence processes. For example, with fresh-cut apples, a heat treatment of $38^{\circ} \mathrm{C}$ for $4 \mathrm{~d}$ before slicing, reduced respiration rate and softening and increased shelf-life by about $50 \%$ as compared to control apples (Bai et al., 2004). As the same, with fresh-cut melon, heating whole fruit at $50^{\circ} \mathrm{C}$ for $60 \mathrm{~min}$ reduced the respiration rate and moisture loss and increased the sweet aromatic flavours (Lamikanra et al., 2005). However, reports on the effect of heat treatment on the physiology and quality of fresh-cut mangoes are limited.

The aim of this work was to study the impact of hot water treatments on visual, physical and biochemical changes in minimally processed mangoes stored at $6^{\circ} \mathrm{C}$.

\section{Materials and methods}

\subsection{Plant material}

'Keitt' mangoes (Mangifera indica L.), imported from Brazil and transported by boat, were purchased from a local supermarket. Fruits of uniform size $(391 \pm 30 \mathrm{~g})$ and maturity stage (based on internal color and firmness) with absence of visible wounds were selected. Upon arrival at the laboratory, fruit were transferred to ambient temperature and kept overnight before testing.

\subsection{Process}

\subsubsection{Heat treatments}

Whole fruit were washed in chlorinated water (100 ppm free chlorine) for $10 \mathrm{~min}$ and randomly distributed for each condition. The heat treatment was performed by hot water dipping (HWD) at 46 or $50^{\circ} \mathrm{C}$ for 30 or $75 \mathrm{~min}$. After dipping, fruit were cooled in water at $13^{\circ} \mathrm{C}$ for $15 \mathrm{~min}$. For each condition 15 fruit were treated, then 10 fruit were minimally processed and 5 were stored at $20^{\circ} \mathrm{C}$ for $24 \mathrm{~h}$ before respiration rate measurements. Non-treated fruit were used as a control.

\subsubsection{Minimal processing}

Fruit were peeled, sliced into cubes $(2 \times 2 \mathrm{~cm})$, washed in $10 \mathrm{ppm}$ sodium hypochlorite and dried with blotting paper. From each treatment, approximately 200 cubes were obtained from 10 fruit and were randomly distributed in four 1 L glass jars ( $\approx 50$ cubes/jar). The jars allowed maintenance of high relative humidity and an ambient atmosphere around the samples and were stored at $6{ }^{\circ} \mathrm{C}$ for $9 \mathrm{~d}$.

\subsection{Quality analysis}

Samples of minimally processed mangoes were taken for quality analysis at 0, 3, 6 and $9 \mathrm{~d}$. Ten cubes of mangoes per treatment were taken from the four jars for the evaluation of visual appearance, firmness, color and measurements of total soluble solids, $\mathrm{pH}$, and acidity. Ten cubes (approx. $8 \mathrm{~g}$ ) were also taken for the anitoxidant extraction (ascorbic acid and carotenoids) and malonyldialdehyde analysis. In this case, samples were immediately frozen in liquid $\mathrm{N}_{2}$ before storage at $-80^{\circ} \mathrm{C}$ and prior to analysis, samples were ground under liquid $\mathrm{N}_{2}$.

\subsubsection{Sensory quality score}

Three judges scored the slices of mangoes for changes in color, visible structural integrity, taste and odor. The visual quality score was based on the following scale: 5 , excellent, just sliced; 4 , very good; 3, good, limit of marketability; 2, fair, limit of usability; 1 , poor, inedible.

\subsubsection{Firmness $(N)$}

Firmness measurements (Penefel texture analyser, Setop Giraud-Technologie, France) were taken as the force required for a $2 \mathrm{~mm}$ stainless steel probe to penetrate the cut surface of mango cubes, held perpendicular to the probe. Firmness was reported as force in newtons $(\mathrm{N})$.

\subsubsection{Color}

Color measurements were performed using a Minotla (CR-300 with a D65 light source; Minolta Camera Co., Osaka, Japan) based on the CIELAB color parameters $L^{*}, a^{*}$ and $b^{*}$ in which $L^{*}$ defines the lightness and $a^{*}$ and $b^{*}$ are the two chromatic components and are from green to red, and blue to yellow, respectively. A standard white calibration plate was used (Charles et al., 2008).

\subsubsection{Total soluble solids (TSS), $p H$ and acidity}

Immediately after firmness and color measurements were made, samples were stored at $-20^{\circ} \mathrm{C}$ before biochemical analysis (TSS, pH and acidity). Juice samples were prepared by blending and thoroughly mixing mango cubes. Total soluble solids (TSS) was assessed with a Digital Hand-held "Pocket" Refractometer PAL-1 (Atago, Japan) and expressed as a percentage. Acidity was determined by titration of mango juice with $0.1 \mathrm{M} \mathrm{NaOH}$ solution to $\mathrm{pH} 8.1$ (using a pH meter). The acidity was expressed as \% of citric acid.

\subsubsection{Ascorbic acid evaluation}

Ascorbic acid (AsA) concentration was measured according to Kampfenkel et al. (1995), scaled down for micro-plates (Power Wave HT, Bio. Tek). Frozen mango fruit powder $(0.3 \mathrm{~g})$ was homogenized in $1 \mathrm{~mL}$ of $6 \%(\mathrm{w} / \mathrm{v})$ TCA. The homogenate was centrifuged at $16,000 \times \mathrm{g}$ at $4{ }^{\circ} \mathrm{C}$ for $15 \mathrm{~min}$. The supernatant was used for AsA determination. For ascorbate, $10 \mu \mathrm{L}$ of extract were added to $40 \mu \mathrm{L}$ of phosphate buffer $(0.2 \mathrm{mM}, \mathrm{pH} 7,4)$ and $150 \mu \mathrm{L}$ of a specific reagent $\left(50 \mu \mathrm{L} 10 \% \mathrm{TCA}, 40 \mu \mathrm{L} 42 \%(\mathrm{v} / \mathrm{v}) \mathrm{H}_{3} \mathrm{PO}_{4}, 40 \mu \mathrm{L} 4 \%(\mathrm{w} / \mathrm{v})\right.$ 2.2-bipyridyl dissolved in $70 \%$ ethanol and $20 \mu \mathrm{L} \mathrm{3 \%}(\mathrm{w} / \mathrm{v}) \mathrm{FeCl}_{3}$. After $40 \mathrm{~min}$ at $42^{\circ} \mathrm{C}$, the absorbance was measured at $\lambda=525 \mathrm{~nm}$ in a micro-plate reader (Power Wave HT, Bio. Tek). Commercial L-ascorbic acid was used for calibration.

\subsubsection{Extraction and analysis of carotenoids}

According to Lichtenthaler and Buschmann (2001), frozen mango fruit powder $(0.3 \mathrm{~g})$ was extracted with $1 \mathrm{~mL}$ of pure acetone. Then the mixture was homogenized for $1 \mathrm{~min}$ and incubated at $4{ }^{\circ} \mathrm{C}$ in darkness until the cap turned white. The homogenate was centrifuged at $16,000 \times g$ for $15 \mathrm{~min}$ and $200 \mu \mathrm{L}$ of supernatant from each tube were placed in 96-well plates. The absorbance was read at $\lambda=470 \mathrm{~nm}$ in a micro-plate reader (Power Wave HT, Bio. Tek). The concentration of total carotenoids was calculated as follows: $C(\mu \mathrm{g} / \mathrm{mL})=\left(1000 \times A_{470}\right) / 214$, and expressed as $\mathrm{mg} / 100 \mathrm{~g}$ fresh weight.

\subsubsection{Malondialdehyde content (MDA)}

The thiobarbituric acid (TBA) test which determines malondialdehyde (MDA) as an end product of lipid peroxidation was used 

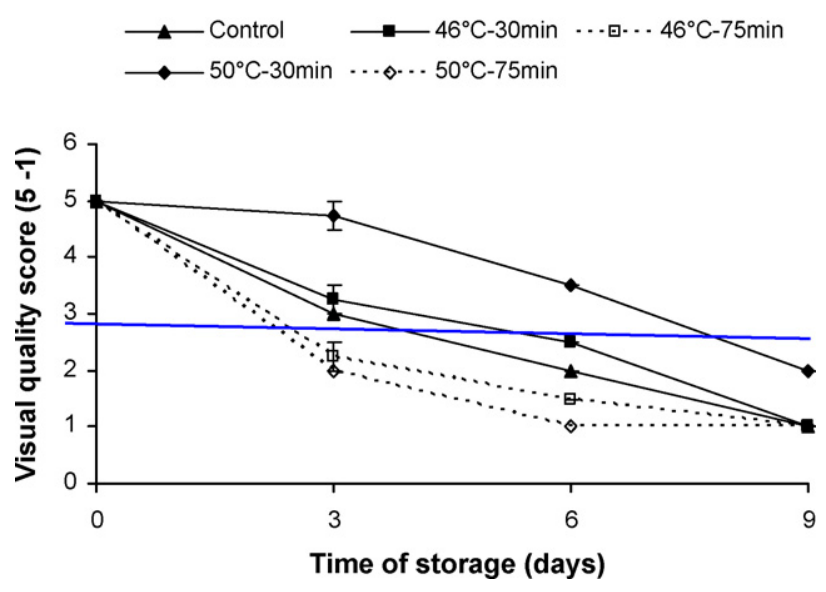

Fig. 1. Effect of HWD on visual quality score of fresh-cut mangoes (cv. Keitt) during storage at $6{ }^{\circ} \mathrm{C}$ (horizontal line represents the acceptable limit for consumption).

(Vilikova et al., 2000). Frozen mango fruit powder $(0.25 \mathrm{~g})$ was homogenized in $1 \mathrm{~mL}$ of $0.1 \%(\mathrm{w} / \mathrm{v})$ TCA. The homogenate was centrifuged at $12,000 \times \mathrm{g}$ for $15 \mathrm{~min}$, and $0.5 \mathrm{~mL}$ of the supernatant was added to $1 \mathrm{~mL}$ of $0.5 \%(\mathrm{w} / \mathrm{v})$ TBA in $20 \%$ TCA, incubated in boiling water for $30 \mathrm{~min}$, and stopped at $0{ }^{\circ} \mathrm{C}$ for $10 \mathrm{~min}$. The absorbance was read at $\lambda=532 \mathrm{~nm}$ in a micro-plate reader (Power Wave HT, Bio. Tek). The amount of MDA-TBA complex (red pigment) was calculated from the extinction coefficient $155 \mathrm{mmol} \mathrm{L}^{-1} \mathrm{~cm}^{-1}$.

\subsection{Respiration rate of mango fruit}

Respiration rate of whole mangoes was determined by the closed system method at $22^{\circ} \mathrm{C}$. One fruit was put in a jar $(6 \mathrm{~L}$, hermetically closed and gas concentrations $\left(\mathrm{O}_{2}, \mathrm{CO}_{2}\right)$ were checked every hour (gas analyser Chekmate 9900, PBI Dansensor, Denmark). The respiration rates were measured as $\mathrm{O}_{2}$ uptake and $\mathrm{CO}_{2}$ emission $\left(\mathrm{RR}_{\mathrm{O} 2}, \mathrm{RR}_{\mathrm{CO} 2}\right)$ and calculated and expressed in $\mathrm{mmol} \mathrm{kg} \mathrm{k}^{-1} \mathrm{~h}^{-1}$ (Varoquaux et al., 2002).

\subsection{Statistical analysis}

Four replicates per treatment were done and analysis of variance (ANOVA) was applied to the results. The means were compared by the Fisher test at a significant level of 0.05 . For respiration rate, means \pm S.E. (standard error) were used.

\section{Results and discussion}

\subsection{Influence of HWD on the sensory quality of fresh-cut mangoes}

Appearance is a major criterion for determining the acceptability of products. It is currently used as an indicator of freshness and quality in fresh-cut research and industry (Cantwell and Suslow, 2002). In this study, visual quality scores decreased after $3 \mathrm{~d}$ to 3 (good and limit of marketability) for the control sample and to 2.25 and 2 (fair and limit of usability) for the HWD 46 and $50^{\circ} \mathrm{C} / 75$ min treatments, respectively (Fig. 1 ). In contrast, the score for fruit treated by HWD $50^{\circ} \mathrm{C} / 30$ min was significantly higher during storage with values of 4.75 (very good), 4 and 2 after 3, 6 and 9 $\mathrm{d}$, respectively. This result focused on the importance of a precise selection of time and temperature for a treatment to increase the shelf-life of fresh-cut mangoes. Koukounaras et al. (2007) found that $\mathrm{HWD} 50^{\circ} \mathrm{C} / 10 \mathrm{~min}$ applied $4 \mathrm{~h}$ before cutting improved the visual quality of fresh-cut peach. The present study led us to select the HWD $50^{\circ} \mathrm{C} / 30 \mathrm{~min}$ as an optimal combination to improve the

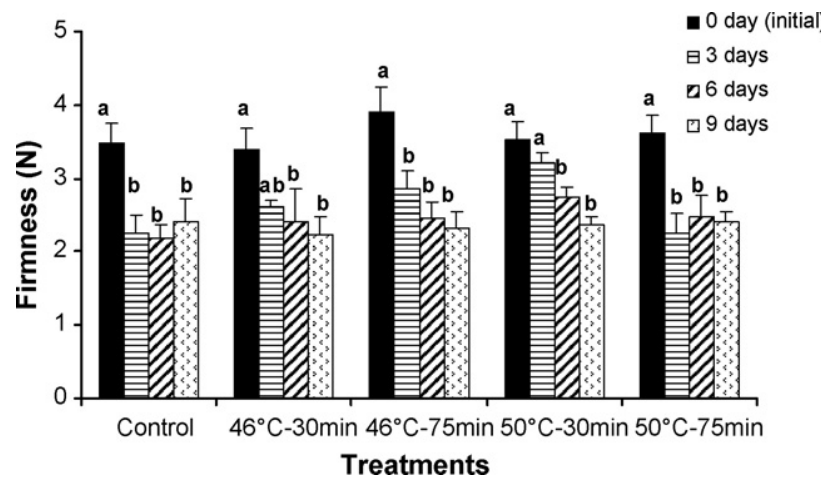

Fig. 2. Effect of HWD on firmness of fresh-cut mangoes (cv. Keitt) during storage at $6^{\circ} \mathrm{C}$ for $9 \mathrm{~d}$ (vertical bars represent standard error of the mean and different letters indicate significant differences for each treatment during storage).

visual quality of 'Keitt' mangoes and keep the product visually acceptable until $6 \mathrm{~d}$ at $6^{\circ} \mathrm{C}$.

\subsection{Influence of HWD on firmness of fresh-cut mangoes}

Firmness changes during the storage of fresh-cut mangoes are shown in Fig. 2. After processing (time 0), firmness values were similar between treatments and then decreased during storage. Chatanawarangoon (2000) has proposed that firmness loss of freshcut mangoes during storage at $5{ }^{\circ} \mathrm{C}$ was due to the release of water. But in our experiment no significant water loss (estimated by drying samples at $80^{\circ} \mathrm{C}$ ) was observed during storage (data not shown).

Differences in firmness decrease were observed between treatments (Table 1). After $3 \mathrm{~d}$, firmness loss was highest in the control and $\mathrm{HWD} 50^{\circ} \mathrm{C} / 75 \mathrm{~min}$ ( $35.1 \%$ and $38.1 \%$ losses, respectively). As reported by many authors, the firmness loss could be linked to softening-related enzymes, such as polygalacturonase (Lazan et al., 1986), galactosidases (Ali et al., 1995), pectin methylesterase and $\beta$-1,4-glucanases (Ali et al., 2004). Conversely, HWD $50^{\circ} \mathrm{C} / 30 \mathrm{~min}$ showed a firmness loss of only $9 \%$ (Table 1 ) and, in Fig. 2, this loss was not significantly different from the initial value. This result suggested that $\mathrm{HWD} 50^{\circ} \mathrm{C} / 30$ min maintained firmness during 3 d of storage at $6^{\circ} \mathrm{C}$. According to Shalom et al. (1996) inhibition of

Table 1

Losses in firmness, $L^{*}$ and $b^{*}$ values of pre-cutting heat-treated fresh-cut mangoes during the storage at $6{ }^{\circ} \mathrm{C}$ expressed as a percentage (\%) compared to the initial value.

\begin{tabular}{lccc}
\hline Treatments & \multicolumn{2}{c}{ Time of storage (days) } \\
\cline { 2 - 4 } & 3 & 6 & 9 \\
\hline Firmness loss (\%) & & 37.1 & 30.9 \\
Control & 35.1 & 28.9 & 34.5 \\
$46^{\circ} \mathrm{C}-30 \mathrm{~min}$ & 22.6 & 37.1 & 40.4 \\
$46^{\circ} \mathrm{C}-75 \mathrm{~min}$ & 26.8 & 22.5 & 33.1 \\
$50^{\circ} \mathrm{C}-30 \mathrm{~min}$ & $9.0^{\mathrm{a}}$ & 31.5 & 33.5 \\
$50^{\circ} \mathrm{C}-75 \mathrm{~min}$ & 38.1 & & \\
$L^{*}$ value loss (\%) & & 14.3 & 22.5 \\
Control & 15.0 & 16.5 & 23.1 \\
$46^{\circ} \mathrm{C}-30 \mathrm{~min}$ & 13.6 & 13.8 & 19.6 \\
$46^{\circ} \mathrm{C}-75 \mathrm{~min}$ & $9.9^{\mathrm{a}}$ & 15.6 & 19.2 \\
$50^{\circ} \mathrm{C}-30 \mathrm{~min}$ & $9.3^{\mathrm{a}}$ & 18.7 & 19.5 \\
$50^{\circ} \mathrm{C}-75 \mathrm{~min}$ & 18.1 & & \\
$b^{*}$ value loss $(\%)$ & & 16.4 & 29.4 \\
$\mathrm{Control}$ & 13.0 & 7.4 & 22.8 \\
$46^{\circ} \mathrm{C}-30 \mathrm{~min}$ & 0.7 & 18.7 & 25.5 \\
$46^{\circ} \mathrm{C}-75 \mathrm{~min}$ & 8.1 & $3.2^{\mathrm{a}}$ & $0.0^{\mathrm{a}}$ \\
$50^{\circ} \mathrm{C}-30 \mathrm{~min}$ & $-4.1^{\mathrm{a}}$ & 23.3 & 23.4 \\
$50^{\circ} \mathrm{C}-75 \mathrm{~min}$ & 18.5 & & \\
\hline
\end{tabular}

a Indicates significant difference. 

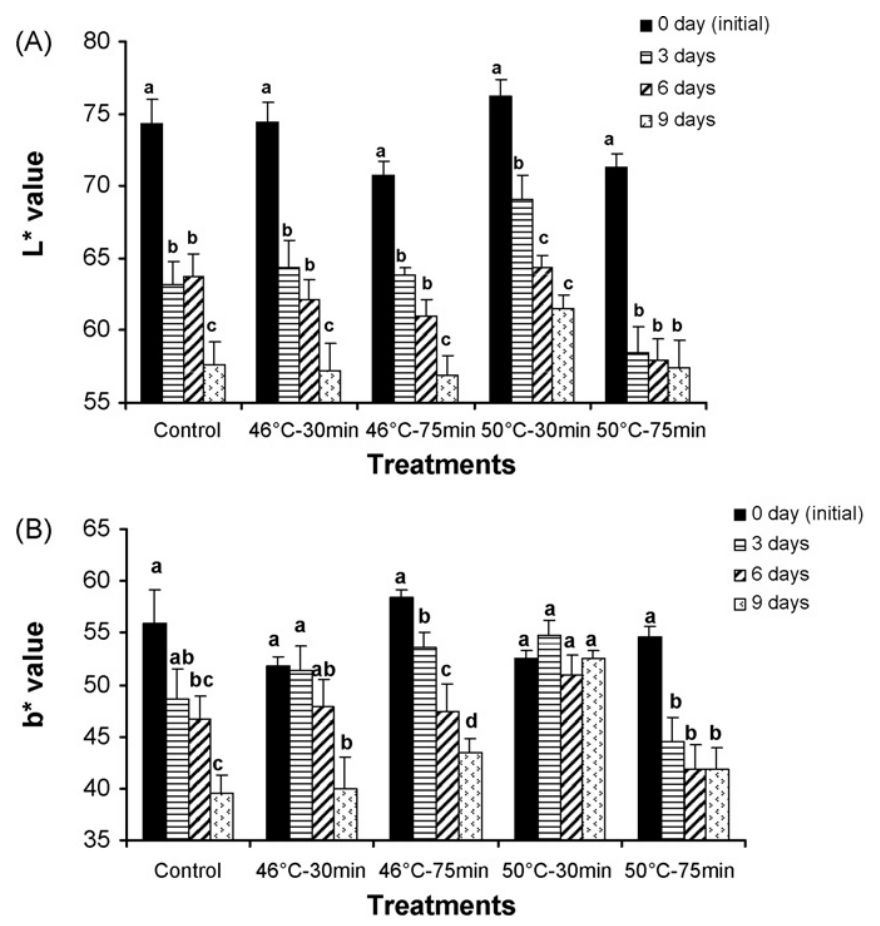

Fig. 3. Changes in $L^{*}(\mathrm{~A})$ and $b^{*}(\mathrm{~B})$ values for 'Keitt' fresh-cut mangoes after HWD (vertical bars represent standard error of the mean and different letters indicate significant differences for each treatment during storage).

solubilisation of the carbonate-soluble pectin fraction is one of the main factors contributing to firmness retention due to heat treatment. Several authors have reported this effect. Kim et al. (1993) have observed on several apple cultivars a significant maintenance of firmness depending on variety and heat treatment conditions. Abreu et al. (2003) have also shown that HWD $40^{\circ} \mathrm{C} / 105$ min maintained the firmness of fresh-cut 'Rocha' pears during $4 \mathrm{~d}$ at $2{ }^{\circ} \mathrm{C}$. Heat-treated kiwifruit at $45^{\circ} \mathrm{C}$ for 25 and 75 min showed also an increment in firmness (Beirão-da-Costa et al., 2006). In this study, after $6 \mathrm{~d}$, and whatever the treatment, no significant protection of firmness was observed.

\subsection{Influence of HWD on color change of fresh-cut mangoes}

Before processing, the color of the skin of whole 'Keitt' fruit was visually estimated and measured by colorimetry. Compared to the control, heat-treated fruit had a higher $b^{*}$ value (data not shown), indicating yellowing of the skin as previously reported by SegarraCarmona et al. (1990).

The color of the pulp was then analysed and expressed by $L^{*}$ and $b^{*}$ values (Fig. 3A and B). The initial $L^{*}$ values for the HWD 46 and $50{ }^{\circ} \mathrm{C} / 75$ min were significantly lower than for the other conditions. These results emphasized the influence of the duration of treatment on the reduction of $L^{*}$ value (Fig. $3 \mathrm{~A}$ ). Then, for each condition, the $L^{*}$ value decreased during storage, as has been described for fresh-cut mangoes of several varieties: 'Tommy Atkins', 'Ataulfo', 'Kent' and 'Keitt' (Rattanapanone et al., 2001; Gonzalez-Aguilar et al., 2008). However, the percentage of $L^{*}$ loss (Table 1 ), showed that after $3 \mathrm{~d}$, the two HWD $46^{\circ} \mathrm{C} / 75 \mathrm{~min}$ and $50^{\circ} \mathrm{C} / 30$ min treatments showed a slight loss of $L^{*}$ with only $9.9 \%$ and $9.3 \%$ decreases, respectively.

Values for $b^{*}$ decreased during storage for all conditions except for HWD $50^{\circ} \mathrm{C} / 30 \mathrm{~min}$ (Fig. 3B; Table 1). Indeed, with this treatment, the color of fresh-cut mangoes was maintained, with significantly less browning than with the other conditions. This result suggested that $\mathrm{HWD} 50^{\circ} \mathrm{C} / 30 \mathrm{~min}$ is a potential alternative to preserve the initial color of mango and protect against browning. Other work has described the influence of heat treatment on the prevention of browning of fresh-cut endive (Salman et al., 2007). It can be noted that high temperature and a long period of treatment such as HWD $50^{\circ} \mathrm{C} / 75 \mathrm{~min}$, quickly reduced $b^{*}$ values and damaged the product.

\subsection{Influence of HWD on total soluble solids (TSS), $\mathrm{pH}$ and acidity of fresh-cut mangoes}

As shown in Table 2, initial TSS contents, excepted for HWD $46^{\circ} \mathrm{C} / 75 \mathrm{~min}$, were similar whatever the conditions (approx. $12.8 \% \pm 0.6)$. Then, there was a slight decrease which didn't match with the normal ripening process characterised by starch degradation to soluble sugars and an increase in the soluble solids values. The HWD $50^{\circ} \mathrm{C} / 30 \mathrm{~min}$ also induced a slight decrease until $6 \mathrm{~d}$, but after $9 \mathrm{~d}$ of storage the final TSS value was higher than at the beginning of the experiment. In contrast, other authors have reported that a quarantine heat treatment applied to nectarines had no effect on TSS content (Obenland et al., 1999). The pH of mango samples, around 4, the usual value for fruit, and the acidity were not significantly affected by heat treatments. These results are in accordance with Abreu et al. (2003) who have demonstrated that heating whole pear fruit from 35 to $45^{\circ} \mathrm{C}$ for $40-150$ min maintained $\mathrm{pH}$ during 7 d of storage at $2{ }^{\circ} \mathrm{C}$.

\subsection{Influence of HWD on ascorbic acid content of fresh-cut mangoes}

Fruit are natural source of ascorbic acid (vitamin C) and it is known that its level decreases during processing and ripening (Lee and Kader, 2000). Moreover, as the oxidative processes occur more rapidly in fresh-cut products, they are expected to have higher losses (Allong et al., 2000). In this study, initial contents of vitamin C were similar after all treatments (Fig. 4) but changes during storage were different among treatments. In control samples, the amount of vitamin $\mathrm{C}$ was maintained until $6 \mathrm{~d}$ before decreasing. HWD $50^{\circ} \mathrm{C} / 30$ min and $46^{\circ} \mathrm{C} / 75$ min maintained the contents until $3 \mathrm{~d}$ and $\mathrm{HWD} 46^{\circ} \mathrm{C} / 30$ min and $50^{\circ} \mathrm{C} / 75$ min quickly decreased the

Table 2

Effect of different HWT on changes in total soluble solids (TSS), $\mathrm{pH}$ and acidity of fresh-cut mangoes during storage at $6^{\circ} \mathrm{C}$ for $9 \mathrm{~d}$.

\begin{tabular}{|c|c|c|c|c|}
\hline & \multicolumn{4}{|c|}{ Time of storage (days) } \\
\hline & 0 (initial) & 3 & 6 & 9 \\
\hline \multicolumn{5}{|l|}{ TSS (\%) } \\
\hline Control & 12.2 a $\mathrm{A}$ & 11.3 a $\mathrm{A}$ & 11.8 a $\mathrm{AB}$ & 11.3 a $\mathrm{A}$ \\
\hline $46^{\circ} \mathrm{C}-30 \mathrm{~min}$ & 13.0 a $\mathrm{A}$ & $12.0 \mathrm{ab} \mathrm{AB}$ & $12.2 \mathrm{ab} \mathrm{AB}$ & $11.9 \mathrm{~b} \mathrm{~A}$ \\
\hline $46^{\circ} \mathrm{C}-75 \mathrm{~min}$ & 13.8 a B & $13.1 \mathrm{ab} C$ & $12.5 \mathrm{~b} \mathrm{~A}$ & $12.9 \mathrm{ab} B$ \\
\hline $50{ }^{\circ} \mathrm{C}-30 \mathrm{~min}$ & $12.7 \mathrm{ab} A$ & $12.3 \mathrm{~b} \mathrm{~B}$ & $12.3 \mathrm{~b} \mathrm{~A}$ & 13.3 c B \\
\hline $50{ }^{\circ} \mathrm{C}-75 \mathrm{~min}$ & 12.4 a A & $11.6 \mathrm{bc} \mathrm{AB}$ & 11.0 c B & $11.6 \mathrm{c} \mathrm{A}$ \\
\hline \multicolumn{5}{|c|}{ Acidity (\% citric acid) } \\
\hline Control & 3.6 a $\mathrm{A}$ & $5.4 \mathrm{~b} \mathrm{AB}$ & $5.3 \mathrm{~b} \mathrm{~A}$ & $5.7 \mathrm{~b} \mathrm{~A}$ \\
\hline $46^{\circ} \mathrm{C}-30 \mathrm{~min}$ & 5.7 a B & 6.4 a A & 5.2 a A & 6.0 a A \\
\hline $46^{\circ} \mathrm{C}-75 \mathrm{~min}$ & 4.6 a $\mathrm{AB}$ & 5.3 a B & 5.3 a A & 4.4 a B \\
\hline $50^{\circ} \mathrm{C}-30 \mathrm{~min}$ & 5.3 a B & 5.6 a $\mathrm{AB}$ & 5.3 a A & 5.3 a $\mathrm{AB}$ \\
\hline $50{ }^{\circ} \mathrm{C}-75 \mathrm{~min}$ & $4.4 \mathrm{a} A B$ & $6.3 \mathrm{~b} \mathrm{AB}$ & $5.3 \mathrm{ab} A$ & 4.8 a $\mathrm{AB}$ \\
\hline \multicolumn{5}{|l|}{$\mathrm{pH}$} \\
\hline Control & 4.2 a $\mathrm{A}$ & $4.1 \mathrm{ab} A$ & $4.1 \mathrm{ab} A B$ & 4.0 с A \\
\hline $46^{\circ} \mathrm{C}-30 \mathrm{~min}$ & 3.8 a B & 4.0 a $\mathrm{A}$ & 4.0 a $A B$ & 3.8 a A \\
\hline $46^{\circ} \mathrm{C}-75 \mathrm{~min}$ & 4.2 a $\mathrm{A}$ & 4.0 a $\mathrm{A}$ & 4.3 a $\mathrm{A}$ & 4.0 a $\mathrm{A}$ \\
\hline $50{ }^{\circ} \mathrm{C}-30 \mathrm{~min}$ & 4.3 a $\mathrm{A}$ & $4.0 \mathrm{~b} \mathrm{~A}$ & $4.1 \mathrm{ab} A B$ & $4.1 \mathrm{ab} A$ \\
\hline $50{ }^{\circ} \mathrm{C}-75 \mathrm{~min}$ & $4.1 \mathrm{a} \mathrm{A}$ & $4.1 \mathrm{a} \mathrm{A}$ & 3.9 a B & $4.1 \mathrm{a} \mathrm{A}$ \\
\hline
\end{tabular}

Same lower case letters in the same horizontal line indicate no-significant differences during storage time. Same capital letters in vertical line indicate no-significant differences between treatments. 


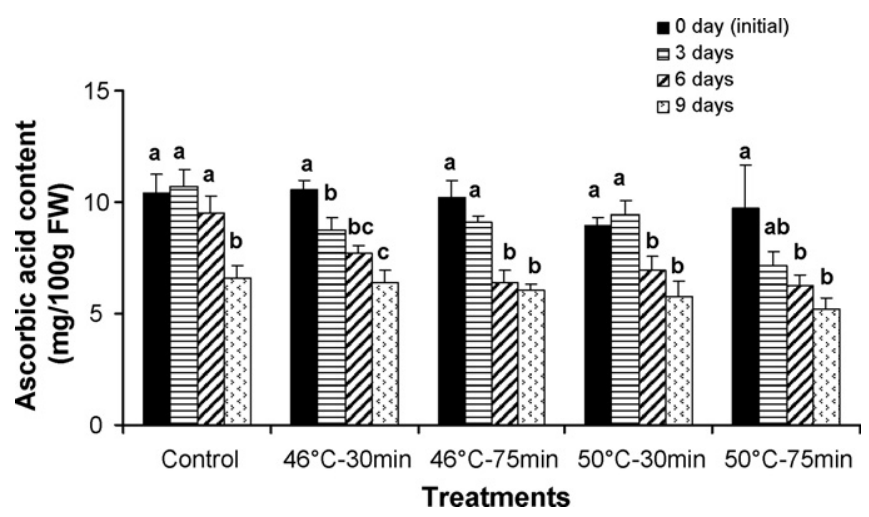

Fig. 4. Effect of HWD on ascorbic acid content of fresh-cut mangoes (cv. Keitt) during storage at $6^{\circ} \mathrm{C}$ for $9 \mathrm{~d}$ (vertical bars represent standard error of the mean and different letters indicate significant differences for each treatment during storage).

vitamin $C$ content. It is clear that heat treatment induced a decrease in the amount of vitamin $C$ as compared to the control. Yahia et al. (2007) have reported that ascorbic acid levels were higher in control tomatoes than in heat-treated fruit $\left(38^{\circ} \mathrm{C}\right.$ or $34^{\circ} \mathrm{C}$ for $\left.24 \mathrm{~h}\right)$. However, with a proper time-temperature combination, like HWD $50^{\circ} \mathrm{C} / 30 \mathrm{~min}$, this decrease can be reduced and fresh-cut products can still contain significant amounts of vitamin C during the storage.

\subsection{Influence of HWD on total carotenoids contents of fresh-cut mangoes}

Carotenoids are pigments responsible for the yellow color of products and have a protective function against oxidative damage. In this study, three treatments $\left(46^{\circ} \mathrm{C} / 75 \mathrm{~min} ; 50^{\circ} \mathrm{C} / 30 \mathrm{~min}\right.$ and $50^{\circ} \mathrm{C} / 75 \mathrm{~min}$ ) resulted in increases in the initial level of total carotenoids compared to the control (Fig. 5). Heat treatment can induce cell membrane disruption and enhance chemical extractability of total carotenoids (Kidmose et al., 2002). During storage, total carotenoid contents remained stable in the control and HWD $46^{\circ} \mathrm{C} / 30$ min treatment, whereas for the other treatments it decreased. It is known that exposure of mangoes to oxygen, peroxides, temperature and light may cause undesirable alterations in structure and bioactivity of carotenoids in terms of isomerisation, oxidation or degradation (Van den Berg et al., 2000). Lower total carotenoid contents during storage have also been reported after heat treatment of whole persimmon fruit (Luo, 2006) and fresh-cut peach (Koukounaras et al., 2007). However, it can be noted that after $3 \mathrm{~d}$, HWD $50^{\circ} \mathrm{C} / 30 \mathrm{~min}$ induced high carotenoid contents as com-

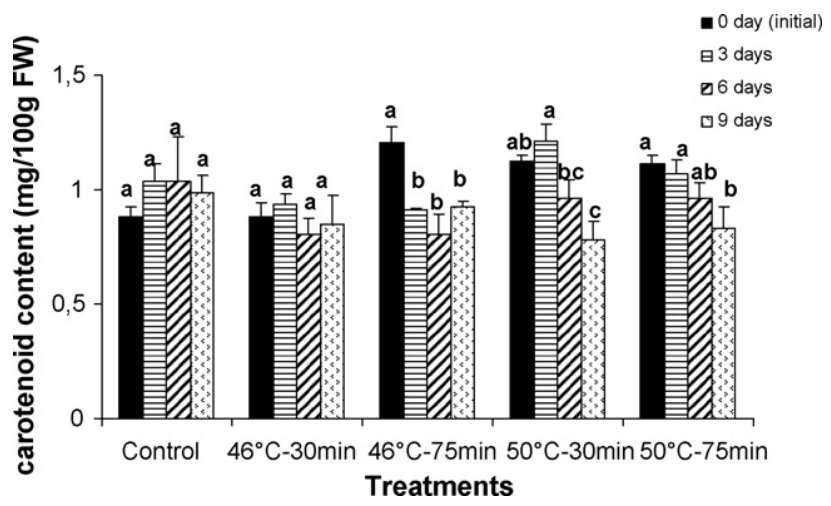

Fig. 5. Effect of HWD on total carotenoids content of fresh-cut mangoes (cv. Keitt) during storage at $6{ }^{\circ} \mathrm{C}$ for $9 \mathrm{~d}$ (vertical bars represent standard error of the mean and different letters indicate significant differences for each treatment during storage).

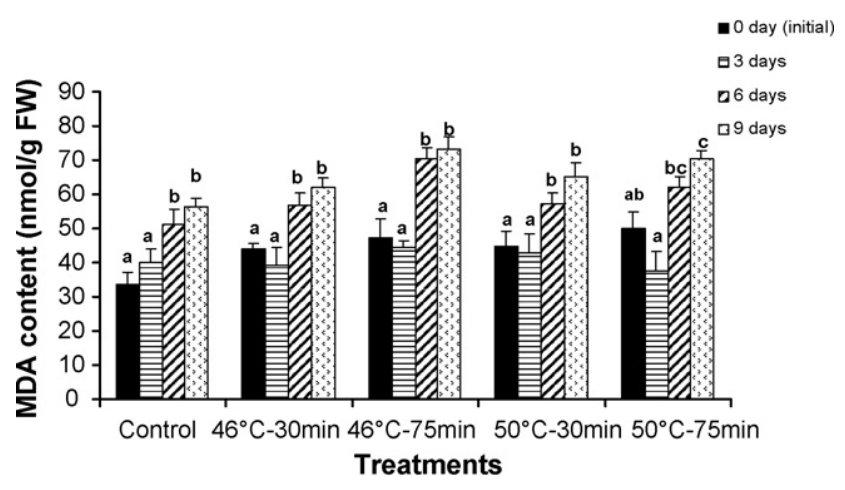

Fig. 6. Effect of HWD on malondialdehyde content (MDA) of fresh-cut mangoes (cv. Keitt) during storage at $6{ }^{\circ} \mathrm{C}$ for $9 \mathrm{~d}$ (vertical bars represent standard error of the mean and different letters indicate significant differences for each treatment during storage).

pared to the control and the other treatments. HWD $50{ }^{\circ} \mathrm{C} / 30 \mathrm{~min}$ could increase the antioxidant capacity of mangoes at this time of storage.

\subsection{Influence of HWD on malondialdehyde content (MDA) of fresh-cut mangoes}

Initial MDA values (Fig. 6) were higher for heat-treated samples as compared to the control. After $3 \mathrm{~d}$, MDA values were maintained whatever the treatment and then increased for all treatments and mainly for HWD 46 and $50^{\circ} \mathrm{C} / 75 \mathrm{~min}$. This result suggests that a long duration of heat treatment induced senescence processes involving lipid peroxidation. No information about the effect of heat treatment on the MDA changes in mango fruit has been reported but an MDA increase was observed in 'Tainong' mango fruit after 3 d of storage at $4{ }^{\circ} \mathrm{C}$ (Wang et al., 2007).

\subsection{Influence of HWD on the respiration rate of whole mangoes}

The results shown in Table 3 , suggest that $\mathrm{HWD} 50^{\circ} \mathrm{C} / 30 \mathrm{~min}$ reduced significantly $\mathrm{RR}_{\mathrm{O} 2}$ as compared to the other treatments and control, whereas $\mathrm{RR}_{\mathrm{CO} 2}$ remained similar whatever the treatment. Similarly, in apples, the respiration is lower upon return of heated fruit to ambient temperature compared to non-heated fruit (Klein and Lurie, 1990). The respiration rate is an indicator of metabolic activity and gives an indication of the potential shelf-life of the product (Church and Parsons, 1995). These results indicated that HWD $50^{\circ} \mathrm{C} / 30 \mathrm{~min}$ could increase the shelf-life of fresh-cut mangoes by decreasing $R_{02}$ of whole mangoes. It suggested use of $\mathrm{RR}_{\mathrm{O} 2}$ as an indicator of the overall influence of a heat treatment on the product shelf-life. The respiratory quotient $\left(\mathrm{RQ}=\mathrm{RRCO} \mathrm{R}_{2} / \mathrm{RRO}_{2}\right)$ ranged between 0.8 and 1.2 (Table 3 ) and the higher value was for HWD $50^{\circ} \mathrm{C} / 30 \mathrm{~min}$. The value of RQ depended on the metabolic substrate of respiration and generally ranged from 0.7 to 1.3 for aerobic respiration (Forcier et al., 1987). In this experiment, heat

Table 3

Respiration rate $\left(\mathrm{RR}_{\mathrm{O} 2} ; \mathrm{RR}_{\mathrm{CO} 2}\right)$ and respiratory quotient $(\mathrm{RQ})$ for hot water treated and untreated 'Keitt' mangoes after $24 \mathrm{~h}$ storage at $22^{\circ} \mathrm{C}$.

\begin{tabular}{lrll}
\hline Treatments & \multicolumn{1}{c}{$\mathrm{RR}_{\mathrm{O} 2}$} & $\mathrm{RR}_{\mathrm{CO} 2}$ & $\mathrm{RQ}$ \\
\hline Control & $2.8 \pm 0.1$ & $2.4 \pm 0.2$ & $0.9 \pm 0.1$ \\
$46^{\circ} \mathrm{C}-30 \mathrm{~min}$ & $2.4 \pm 0.3$ & $2.4 \pm 0.2$ & $1.0 \pm 0.2$ \\
$46^{\circ} \mathrm{C}-75 \mathrm{~min}$ & $2.9 \pm 0.5$ & $3.0 \pm 0.6$ & $1.0 \pm 0.0$ \\
$50^{\circ} \mathrm{C}-30 \mathrm{~min}$ & $1.9^{\mathrm{a}} \pm 0.2$ & $2.3 \pm 0.2$ & $1.2 \pm 0.1$ \\
$50^{\circ} \mathrm{C}-75 \mathrm{~min}$ & $2.5 \pm 0.3$ & $2.6 \pm 0.2$ & $1.0 \pm 0.1$ \\
\hline
\end{tabular}

a Indicates significant difference. 
treatment did not modify the respiration process of mango fruit. Similarly, Hasbulah et al. (2001) have found that the RQ values of 'Irwin' mango treated with HWD $47.2^{\circ} \mathrm{C} / 60,90$ and 120 min ranged between 0.92 and 1.05 and were not affected by heat treatment.

\section{Conclusion}

This study investigated the effects of different combinations of heat treatment (temperature and duration of application) on the quality of fresh-cut mangoes. A hot water dipping (HWD) $50{ }^{\circ} \mathrm{C} / 30 \mathrm{~min}$ was demonstrated to have the potential to maintain the appearance and color of minimally processed mangoes during 6 and $9 \mathrm{~d}$ of storage at $6^{\circ} \mathrm{C}$, respectively. Compared to the other heat treatments, HWD $50^{\circ} \mathrm{C} / 30$ min maintained firmness and the vitamin $C$ content for up to $3 \mathrm{~d}$. This treatment also increased the total carotenoid contents after $3 \mathrm{~d}$ and decreased the respiration rate of the whole fruit. These results suggest that a HWD of $50^{\circ} \mathrm{C} / 30 \mathrm{~min}$ can be an effective, inexpensive and environmentally safe method to improve the quality of fresh-cut 'Keitt' mangoes.

\section{References}

Abreu, M., Beirão-da-Costa, S., Concalves, E., Beirão-da-Costa, M.L., Moldao-Marins, M., 2003. Use of mild heat pre-treatments for quality retention of fresh-cut 'Rocha' pear. Postharvest Biol. Technol. 30, 135-160.

Ali, Z.M., Armugam, H., Lazan, H., 1995. $\beta$-Galactosidase and its significance in ripening mango fruit. Phytochemistry 38, 1109-1114.

Ali, Z.M., Chin, L.-H., Lazan, H., 2004. A comparative study on wall degrading enzymes, pectin modifications and softening during ripening of selected tropical fruits. Plant Sci. 167, 317-327.

Allong, R., Wickham, L.D., Mohammed, M., 2000. The effect of cultivar, fruit ripeness, storage temperature and duration on quality of fresh-cut mango. Acta Hort. 509, 487-494.

Bai, J., Baldwin, E., Fortuny, R., Mattheis, J., Stanley, R., Perera, C., Brecht, J., 2004. Effect of pre-treatment of intact 'Gala' apple with ethanol vapour, heat, or 1methylcyclopropene on quality and shelf life of fresh-cut slices. J. Am. Soc. Hort. Sci. 129, 583-593.

Beirão-da-Costa, S., Steiner, A., Correia, L., Empis, J., Moldão-Martins, M., 2006. Effects of maturity stage and mild heat treatments on quality of minimally processed kiwifruit. J. Food Eng. 76, 616-625.

Benitez, M.M., Acedo Jr., A.L., Jitareerat, P., Kanlavanarat, S., 2006. Mango fruit softening response to postharvest heat treatment. Acta Hort. 712, 811-816.

Cantwell, M.I., Suslow, T.V., 2002. Postharvest handling systems: fresh-cut fruits and vegetables. In: Kader, A.A. (Ed.), Postharvest Technology of Horticultural Crops. University of California, Davis, pp. 445-463.

Charles, F., Guillaume, C., Gontard, N., 2008. Effect of passive and active modified atmosphere packaging on quality changes of fresh endives. Postharvest Biol. Technol. 48, 22-29.

Charles, F., Sanchez, J., Gontard, N., 2003. Active modified atmosphere packaging of fresh fruits and vegetables: modeling with tomatoes and oxygen absorber. J. Food Sci. 68, 1736-1742.

Charles, F., Sanchez, J., Gontard, N., 2005. Modeling of active modified atmosphere packaging of endives as a function of temperature. J. Food Sci. 70, 443-449.

Chatanawarangoon, S., 2000. Quality maintenance of fresh-cut mango slices. In: Master Thesis. Davis University of California, CA, p. 79.

Church, I.J., Parsons, A.L., 1995. Modified atmosphere packaging technology: a review. J. Sci. Food Agric. 67, 143-152.

Civello, P.M., Martinez, G.A., Añón, M.C., 1997. Heat treatments delay ripening and post harvest decay of strawberry fruit. J. Agric. Food Chem. 45, 4589-4594.

Food and Agriculture Organization. 2005. FAOSTAT database collections, agricultural data, food and agriculture organization of the United Nations. http://www.faostat.fao.org/.

Forcier, F., Raghavan, G.S.V., Gariepy, Y., 1987. Electronic sensor for the determination of fruit and vegetable respiration. Int. J. Refrig. 10, 353-356.

Garcia, J.M., Aguilera, C., Albi, M.A., 1995. Postharvest heat treatment in Spanish strawberry (Fragaria $\times$ ananassa cv. Tulda). J. Agric. Food Chem. 43, 1489-1492.

Gonzalez-Aguilar, G.A., Celis, J., Sotelo-Mundo, R.R., De la Rosa, L.A., Rodrigo-Garcia, J., Alvarez-Parrilla, E., 2008. Physiological and biochemical changes of different fresh-cut mango cultivars stored at $5^{\circ} \mathrm{C}$. Int. J. Food Sci. Technol. 43, 91-101.

Hasbulah, R., Kawasaki, S., Kojima, T., Akinaga, T., 2001. Effect of heat treatments on respiration and quality of 'Irwin' mango. J. Soc. Agri. Struc. 32, 59-67.

Jacobi, K.K., Giles, J.E., 1997. Quality of 'Kensington' mango (Mangifera indica Linn.) fruit following combined vapour heat desinfestation and hot water disease control treatments. Postharvest Biol. Technol. 12, 285-292.
Kader, A.A., 2002. Quality parameter of fresh-cut fruit and vegetable products. In: Lamikanra, O. (Ed.), Fresh-cut Fruits and Vegetables. Science, Technology and Market. CRC Press, pp. 11-20.

Kampfenkel, K., Van Montagu, M., Inze, D., 1995. Extraction and determination of ascorbate and dehydroascorbate from plant tissue. Anal. Biochem. 225, 165167.

Kidmose, U., Edelenbos, M., NØrbaek, R., Christensen, L.P., 2002. Colour stability in vegetables. In: MacDougall, D.B. (Ed.), Colour in Food Improving Quality. CRC Press, Cambridge, UK.

Kim, D.M., Smith, N.L., Lee, C.Y., 1993. Apple cultivar variations in response to heat treatment and minimal processing. J. Food Sci. 58, 1111-1124.

Klein, J.D., Lurie, S., 1990. Prestorage heat treatment as a means of improving poststorage quality of apples. J. Am. Soc. Hort. Sci. 115, 265-269.

Koukounaras, A., Diamantidis, G., Sfakiotakis, E., 2007. The effect of heat treatment on quality retention of fresh-cut peach. Postharvest Biol. Technol. 48, 30-36.

Lamikanra, O., Bett-garber, K., Ingram, D., Watson, M., 2005. Use of mild heat pretreatment for quality retention of fresh-cut cantaloupe melon. J. Food Sci. 70 53-57.

Lazan, H., Ali, Z., Lee, K., Voon, J., Chaplin, G., 1986. The potential role of polygalacturonase in pectin degradation and softening of mango fruit. ASEAN Food J. 2, 93-95.

Lee, S.K., Kader, A.A., 2000. Preharvest and postharvest factors influencing vitamin C content of horticultural crops. Postharvest Biol. Technol 20, 207-220.

Lichtenthaler, H.K., Buschmann, C., 2001. Chlorophylls and carotenoids: measurement and characterization by UV-VIS spectroscopy. Current Protocols in Food Analytical Chemistry. Unit F4 3, 1-8.

Luo, Z., 2006. Extending shelf-life of persimmon (Diospyros kaki L.) fruit by hot air treatment. Eur. Food Res. Technol. 222, 149-154.

Lurie, S., 1998. Postharvest heat treatments of horticultural crops. Hort. Rev. 22 91-121.

Mc Carthy, M.A., Mattews, R.H., 1994. Nutritional quality of fruits and vegetables subject to minimal processed. In: Wiley, R.C.(Ed.), Minimally Processed Refrigerated Fruits and Vegetables. Chapman and hall, New York, p. 313.

Obenland, D.M., Arpaia, M.L., Aung, L.H., 1999. Quality of nectarine cultivars subjected to forced-air heat treatment for Mediterranean fruit fly disinfestations. J. Hort. Sci. Biotechnol. 74, 553-555.

Pittia, P., Nicoli, M.C., Comi, G., Massini, R., 1999. Shelf-life extension of fresh-like ready-to-use pear cubes. J. Sci. Food Agric. 79, 955-960.

Porat, R., Pavoncello, D., Peretz, J., Ben-Yehoshua, A.S., Lurie, S., 2000. Effects of various heat treatments on the induction of cold tolerance and the postharvest qualities of 'Star Ruby Grapefruit'. Postharvest Biol. Technol. 18, 159-165.

Rattanapanone, N., Lee, Y., Wu, T., Watada, A.E., 2001. Quality and microbial changes of fresh-cut mango cubes held in controlled atmosphere. HortScience 36, 1091-1095.

Salman, A., Goupil, P., Filgueiras, H., Charles, F., Ledoigt, G., Sallanon, H., 2007. Controlled atmosphere and heat shock affect PAL1 and HSP90 mRNA accumulation in fresh-cut endive (Cichorium intybus L.). Eur. Food Res. Technol. 227, 721726.

Segarra-Carmona, A.E., Franqui, R.A., Ramirez-Ramos, L.V., Santaigo, L.R., TorresRivera, C.N., 1990. Hot water dip treatments to destroy Anastrepha obliqua larvae (Diptera: Tephritidae) in mangoes from Puerto Rico. J. Agric. Univ. Puerto Rico 74, 441-447.

Shalom, N.B., Hanzon, J., Pinto, R., Lurie, S., 1996. Cell wall changes and partial prevention of fruit softening in prestorage heat treated 'Anna' apples. J. Sci. Food Agric. 72, 231-234.

Shieber, A., Ulrich, W., Carle, R., 2000. Characterization of polyphenols in mango puree concentrate by HPLC with diode array and mass spectrometric detection. Innov. Food. Emerg. Technol., 161-166.

Sudhakar, D.V., Maini, S.B., 1994. Stability of carotenoids during storage of mango pulp. J. Food Sci Technol. 31, 228-230.

Van den Berg, H., Faulks, R., Granado, H.F., Hirschberg, J., Olmedilla, B., Sandmann, G., Southon, S., Stahl, W., 2000. The potential for the improvement of carotenoid levels in foods and the likely systemic effects. J. Sci. Food Agric. 80, 880-912.

Varoquaux, P., Gouble, B., Ducamp, M.N., Self, G., 2002. Procedure to optimize modified atmosphere packaging for fruit. Fruits 57, 313-322.

Varoquaux, P., Wiley, R., 1994. Biological and biochemical changes in minimally processed refrigerated fruits and vegetables. In: Wiley, R.C. (Ed.), Minimally Processed Refrigerated Fruits and Vegetables. Chapman and Hall, New York, pp. 226-268.

Vilikova, V., Yordanove, I., Edreva, A., 2000. Oxidative stress and some antioxidant systems in acid rain-treated bean plants protection role of exogenous polyamines. Plant Sci. 151, 59-66.

Vinci, G., Botre, F., Mele, G., Ruggieri, G., 1995. Ascorbic acid in exotic fruits: a liquid chromatographic investigation. Food Chem. 53, 211-214.

Wang, B., Wang, J., Liang, H., Yi, J., Zhang, J., Lin, L., Wu, Y., Feng, X., Cao, J., Jiang, W. 2007. Reduced chilling injury in mango fruit by 2,4-dichlorophenolxyacetic acid and the oxidant response. Postharvest Biol. Technol. 48, 172-181.

Yahia, E.M., Soto-Zamora, G., Brecht, J.K., Gardea, A., 2007. Postharvest hot air treatment effects on the antioxidant system in stored mature-green tomatoes. Postharvest Biol. Technol. 44, 107-115. 